\title{
Travel Writing
}

\section{Astrid Haas}

Known since antiquity, travel writing has not only enjoyed great popularity in the West, but it has also played a crucial role in the cultural history of the Americas since the late 15th century. Although recordings of pre-contact indigenous travels in the Americas exist (see e.g. Boone 1994), the travelogue as a literary genre was introduced to the region by the European colonizers. It has since been catering to the desire of broadening audiences for geographic and cultural knowledge of unfamiliar places and peoples, for economic, socio-political, or strategic information, as well as for entertainment through captivating stories (Blanton 2002, 7-29). Increasingly diverse, though predominantly Eurocentric for most of its history, the genre has contributed to formulating and circulating hegemonic concepts and "imagined geographies" (Said 1995, 55, 71) of "America" (Rabasa 1993; Mignolo 2005) that inform public discourses, knowledge, and power relations to this day.

\section{Defining travel writing}

Travel writing is a hybrid genre that borders on, as well as incorporates, elements of various other text types such as novels, autobiographies, reports, legends, diaries, letters, tracts, or essays, and may, therefore, be difficult to distinguish from them (Ette 2003, 25-26; Guzmán Rubio 2011, 113-14). Its thematic and formal eclecticism render it a "frictional literature" that oscillates between fictional and factual writing or even challenges their distinction altogether (Ette 2003, 31). Common subdivisions of this body of writing are based on the writers' countries of origin, their travel destinations, or their modes of journeying (Ette 2003, 17; Fernández Bravo 2007, 3-4), on categories of travelers, journeys, or text types like the travel diary or memoir (Blanton 2002, 2-4; Guzmán Rubio 2011, 115-27), or on different approaches to dealing with extratextual reality (Nünning 2008, 27-28). In its broadest sense, "travel writing" may refer to all kinds of texts that depict a physical journey, including accounts openly acknowledging their entirely fictitious nature. Narrow definitions limit the term to denote only narratives of actual travels penned with a subjective, "literary purpose" and the intention of public dissemination (Blanton 2002, 4-5). This chapter takes a middle ground here: it defines the genre as encompassing both private and publication-oriented 
narrative texts that may show different degrees of fictionalization and which are based on actual journeys undertaken by their authors for a variety of possible purposes.

\section{Major characteristics of the genre}

The popularity of travel writing rests on the way it enables readers to engage with cultural, social, and political alterity in a comprehensible manner (Ette 2003, 18-19; Nünning 2008, 16). Western journey narratives of the Modern Era particularly promise to function as a "conduit of knowledge" and experience (Hayward 2016, 362; also Ette 2003, 28-29), based on a traveler's personal testimony of a journey (Blanton 2002, 2; Nünning 2008, 14). However, travelogues are never immediate and objective representations of "reality." Instead, they provide culturally prefigured and literarily mediated notions of places, people, and events as much as factual knowledge. Many journey narratives have further informed subsequent practices of traveling, writing, and reading. To begin with, their personal background and cultural context shape writers' patterns of journeying and perceiving the world (Nünning 2008,12 , 14). For example, although both travelers can be classified as 19th-century sociopolitical observers, differences in gender, social status, and reasons for journeying marked the Chilean sojourn of the English officer's widow Maria Graham and the U.S. American one of the exiled Mexican intellectual Guillermo Prieto (Graham 1969; Prieto 2017). Additionally, available print materials such as earlier travelogues, works of historiography, or graphic prints further mediate a given itinerary or travel destination to travelers even before they leave home. These materials offer models of travel, observation, and description that contribute not only to the way the writers experience and later remember their journeys but also to cultural and genre-specific conventions of representation in the narratives they pen afterward (Ette 2003, 24-25, 40-41; Nünning 2008, 14-16, 21).

Travel writers usually target an audience with whom they share a language and culture and for whom they consider their accounts to be useful or interesting (Ette 2003, 29; Fernández Bravo 2007, 2). Although many journey narratives are based on writers' travel journals, these notes already provide a subjective representation of their experiences. Turning these retrospectively into a travel account implies fashioning them into a coherent, meaningful story by means of selecting, structuring, and narrating the recorded information (Nünning 2008, 20-23; Ette 2003, 36). A linear, chronological order and first-person narrations dominate the genre (Blanton 2002, 4; Nünning 2008, 23), even though object-bound accounts or travel meta-narratives like Jamaica Kincaid's A Small Place also tend to employ non-linear structures 
or integrate alternative narrative perspectives (Kincaid 2000). As they recount the major episodes and places of a journey, chronological travelogues enable audiences to mentally follow and comprehend the travelers' outer and inner movements, and a first-person narrator creates a particularly strong sense of immediacy and intimacy that arouses readers' interest. The narrative situation and structure of most journey narratives thereby tend to conceal the fact that the traveling subject (or narrated I) of a text is a careful construction at the hands of the retrospective narrator (or narrating I), who tells the story of the journey in retrospect. As exemplified paradigmatically in Alexander von Humboldt's writings about his Latin American journey (see e.g. Humboldt and Bonpland 2007), many narrators additionally bolster the credibility of their accounts by complementing the travelers' subjective experiences with information culled from documents or local informants (Ette 2003, 29-38; Nünning 2008, 18, 22, 25).

To further establish the authority and significance of their accounts, travel writers face the task of meaningfully conveying geographic and socio-cultural alterity to readers. Especially since the 19th century, many narrators blend a utilitarian discourse with an aesthetic one in order to appeal to their audiences' reason and emotions (Hume 1999, 311, 315). In a similar vein, they often create a polyphony of voices - albeit often to confirm the narrator's perspective - by recurring to patterns of fictional narration such as interspersing descriptive passages with letters, journal entries, or dialogues (Ette 2003, 24, 26, 83-84). Mário de Andrade's $O$ turista aprendiz, for instance, conveys the language and popular culture of Northern Brazil through song lyrics, conversations, or definitions of regional expressions that are woven into the narrator's diary entries (Andrade 2015, 79-80, 94-96, 116-17, 129-30, 138-39). Explicit or implicit cultural and intertextual references to classical mythology, scripture, volumes of fiction, other travelogues, or historiography serve to affirm the accuracy of the travelers' observations and to position their narratives within their genre and cultural context (Blanton 2002, 1-2; Ette 2003, 18, 24). For example, Meriwether Lewis's fashions himself in his travel journal as heir to explorers Christopher Columbus and James Cook (Journals 2005, 7 Apr. 1805). Yet another strategy of conveying information and opinion are comparisons of unknown places and people to other ones that are known to target audiences. In so doing, travelogues "both familiarize and distance the foreign" (Blanton 2002, 5; also Fernández Bravo 2007, 4). This is particularly relevant, as the representation of the unfamiliar marks the major contribution of the genre to social, political, economic, and cultural discourses. In this vein, Hernán Cortés conveys the cultural advancement and splendor of Mexican cities through references to Spanish towns in his second Carta de Relación (Cortés 1963, 45, 51, 64, 72-74). Some writers, such as the French Protestant Jean de Léry in his juxtaposition of indigenous Brazil and Cath- 
olic France, employ contrasts as a narrative strategy to scrutinize aspects of their own society (Léry 2009, 250-58). However, most travel authors not only affirm the socio-cultural perspectives and interests they share with their sponsors and target readers but also posit the superiority of their own civilization over others (Ette 2003, 24; Nünning 2008, 16).

\section{Recording colonial exploration and conquest}

The tendency of the genre to affirm and legitimize the values, discourses, and agendas of travelers' home societies has rendered travel writing a powerful tool of endeavors of colonialism and imperialism, and this potential has crucially informed journey accounts about the Americas. Since the late 15th century, European explorers and colonizers, followed by their hemispheric descendants, "constructed Commodified Geographies that cast an economic, imperializing eye on the land and its people," Susan Roberson observes (2016, 352 , original spelling). Informed by previous travelogues and popular myths about the "New World" as much as by their own experiences, their journey accounts predominantly frame the region as either "geographies of hardship" or "geographies of awe and wonder:" a perilous and alien wilderness resisting penetration or a "virgin land" whose riches are waiting to be taken (Roberson 2016, 351-56; also Hayward 2016, 361-62, 365). Connected to the geographic discourse, the travelogues depict the Amerindian populations according to their difference from the writers' home societies, usually characterizing sedentary nations as more "civilized" than nomadic ones and those willing to accept European rule and culture as superior to those resisting them. For instance, Hernán Cortés's second letter from his Cartas de Relación (1519-26) to Emperor Charles V describes Mexico as a land offering the Spanish conquerors great wealth. The journey of the Spaniards from the Gulf of Mexico to Tenochtitlán reads like an entangled geographic and civilizational ascent, culminating in the Aztec capital that, despite all differences, bears striking resemblance to Spain, "As large as Sevilla or Córdoba," the city's circular layout recalled the Vitruvian ideal city, and its economy appears to rival the narrator's native one. The letter further naturalizes Aztec emperor Montezuma's submission to Spanish rule by presenting his "inferior" religion as having facilitated the Spanish conquest and the Aztec people as devoid of land rights, as they had migrated to Mexico themselves. (Cortés 1963, 72-73, my trans., 59; Checa 1998, 29-34, 50-52, 60-61; Rabasa 1993, 86, 105, 107-08, 116-17, 120-21).

The early European accounts of the "wonders" of the "New World" quickly captured the public imagination in Europe, as they were circulated widely in popular compilations. In 
presenting and structuring the available knowledge about the non-European world, compendia like Giovanni Battista Ramusio's Delle navigazioni et viaggi (1550-59), Richard Hakluyt's Principal Navigations (1589), or Theodor de Bry's India Occidentalis (1590-1634) influenced the intellectual knowledge formation into the 17th and 18th centuries (van Groesen 2008, 35-49, 352-76; Ette 2003, 74). One of the travelogues most widely anthologized in these collections was the French Calvinist Jean de Léry's Histoire d'un voyage fait en la terre $d u$ Brésil (1578) about his life in the colony France antarctique in Brazil in 1556-58. This volume stands out among the genre depicting the Brazilian Tupinambá nation as a civilization in its own right. The text portrays the Natives as veritable "noble savages," the emblematic cultural figure of indigenous cultural alterity that may either signify an advancement from a brute state of nature or indicate a state of innocence untouched by a corruptive European civilization (Fernández Bravo 2007, 4): The Tupinambá, appear in the French travelogue as godless and nude but handsome and healthy "children of nature." And while de Léry rejected their cannibalism of captured enemies, his narrative does not depict it as a biological deficit but as a cultural practice. The text even evokes it as a contrast to French society, whose exploitation of the poor and persecution of Protestants in the 16th century it scrutinizes as cannibalizing one's own people (Léry 2009, 108-31, 237-67; Jurt 2001, 205-15).

\section{Scientific expedition accounts}

In its detailed ethnographic study of the Tupinambá, De Léry's Histoire d'un voyage prefigures the shift that occurred in European travel writing about the Americas from the 17th to the 19th century toward a more systematic, scientific investigation of the hemisphere. During that period, numerous scientific expeditions were mounted to survey the region's territory and populace. They were informed, on the one hand, by the desire of the colonial powers and their hemispheric successor states to assess the natural resources of their possessions and, on the other, by the emergence of the modern natural sciences. Their written exploration accounts altered the colonial images of the primeval wilderness of the Americas, as they stressed the terrain's potential for economic transformation through settlement and cultivation, especially by people of European descent (Hume 1999, 303, 306, 309-10; Pratt 2008, 23-24, 30, 32-34, 50-51, 59-60). In his Relation historique du voyage aux régions équinoxiales $d u$ Nouveau Continent (1814-25), the German scientist Alexander von Humboldt exemplifies the Eurocentric view of the cultural deficiency of the "New World" when he defines the Americas, in contrast to Europe, primarily through their "wild, gigantic nature" (Humboldt and Bonpland 2007, I: 32, my trans.; Ette 2003, 120; Pérez-Mejía 2004, 
55). Its fecundity and mineral resources simultaneously entail the promise of economic exploitation and the danger of eroding civilization. For instance, the travelogue states that the northern shore of Lake Valencia in Venezuela "is pleasant, bucolic, decorated with rich cultures of sugar cane, coffee, and cotton." However, it also warns that

in the tropics the agricultural nations occupy less ground: man ... may be said to appear, not as an absolute master, who changes at will the surface of the soil, but as a transient guest, who quietly enjoys the gifts of nature.

(Humboldt and Bonpland 2007, I: 360, II: 66, my trans.; Lindquist 2004, 50-58; Pérez-Mejía 2004, 51).

The scientific expedition accounts about the Americas also modified the colonial view of the indigenous nations of the Americas, connecting their "savagery" not only to their presumed lack of civilization in the past and present but also to their assumed inability to acquire it in the future. In so doing, the travelogues naturalized discourses and power structures that favored populations of European origin and legitimized the oppression and displacement of native peoples in the new nation states of the hemisphere (Hume 1999, 308-09; Hayward 2016, 362). This becomes prominently evident in the journals kept by six officers of the U.S. government-sponsored scientific expedition to the Pacific Ocean under the command of Captains Meriwether Lewis and William Clark (1804-06). Here, the Amerindians appear as economically and intellectually deprived, marked by ignorance, poverty, greed, and superstition. "These Indians had the appearance of being very poor, \& set a great value, on the most trifling article," one diary entry reads. Elsewhere in the journals, Lewis dismisses indigenous rituals as superstition and Clark complains about the Oto Indians' insistent begging. Even when entries distinguish among different nations, generalizations prevail, such as "all the Indians from the Rocky mountains to the falls of the Columbia, are an honest, ingenuous and well-disposed people, but from the falls to the sea-coast ... they are a rascally, thieving set" (Journals 2005, 18 Aug. 1805, 13 Apr. 1805, 19 Aug. 1804, 7 May 1806, original spelling and punctuation; Slaughter 2003, 14, 149-53, 161-62, 165-66; Roberson 2016, 353, 357).

\section{Narratives of political observation and social exploration}

While a yet-uncultivated nature and its Amerindian residents continued to represent the "sublime danger" of the "New World," a novel type of European traveler, inspired by 
Romanticist admiration for new beginnings, also came to view the Americas "as a space of ... revolutionary possibilities" (Hayward 2016, 365). The journey accounts this group of visitors penned about the now independent nation states provided studies of the new countries' political systems, economies, and social organization as well as their possible relevance for the visitors' home countries (Ette 2003, 22-23; Pratt 2008, 143-52). As social conditions were considered a suitable topic for women, the new genre also enabled an unprecedented number of female traveler-writers to participate in the international public discourse about the "New World." The travelogues of these social exploratresses (Pratt 2008, 157) are often more personal in tone, novelistic in style, and voicing quests for self-realization through journeying than most male-authored narratives. Nonetheless, through their study of social conditions, these texts contributed to the work of the period's "capitalist vanguard," male travelers scouting the hemisphere for opportunities for European capital investment and mercantile expansion (Pérez-Mejía 2004, 76-78; Pratt 2008, 143-44, 152-58, 165). In her Journal of a Residence in Chile During the Year 1822 (1824), for instance, Maria Graham carefully fashions herself as a conventional woman who only occasionally ventured away from her Valparaíso home and merely noted her personal observations of social manners and domestic life in a private diary. "The most domestic of creatures" by virtue of her being an Englishwoman, she proclaims her distance from active politics: "What have I to do with states or governments?" Her narrator nonetheless connects her personal development as an expatriate gentlewoman to discussions of scientific and economic matters or of Chilean history and politics. Graham's keen ethnographic eye and reflections about her own role in post-colonial Chile make her narrative stand out among the genre. However, while her Journal mystifies the country's indigenous past, it denigrates present-day native life and land claims (Graham 1969, 334, 148; Pérez-Mejía 2004, 4, 78, 84-99; Pratt 2008, 154-60, 168).

This approach to Chile's past and present exemplifies how even self-reflective European visitors like Graham ultimately tended to look upon the Americas with a sense of sociocultural superiority that turns their narratives into media of "imperial intervention in the [cultural] contact zone" (Pratt 2008, 157, also 167; Hayward 2016, 365-66; Roberson 2016, 35859). U.S. American travelers to Latin America from the period followed along similar lines. In contrast, most Latin American-authored journey accounts studying the United States viewed the country as a likely model for their own nations, though increasingly also as a potential threat to Latin America (Fernández Bravo 2007, 3, 12-13; Hayward 2016, 369). The Mexican intellectual Guillermo Prieto's Viaje a los Estados Unidos (1877-78) blends a social study indebted to Humboldtian science with a self-proclaimed "kaleidoscopic" portrayal of 
the country that also integrates satirical reflections on travel and travel writing (Martínez Andrade 2004, 69-73, Prieto 2017, I: viii-ix). As it constantly compares the northern neighbor republic to Mexico, Prieto scrutinizes U.S. American political corruption and social mores yet simultaneously voices admiration for the country's economic prosperity and technological advancement. In contrast to the poverty and illiteracy of the Mexican working class, the text claims, "laborers [in the United States] are citizens who eat with cutlery and read periodicals." Similarly, the Niagara railway figures as a symbol of industrial modernity and progress, as it is "ringing out its triumphant bell, with its summit of smoke and flames suspended above the abyss" it crosses (Prieto 2017, I: 516, II: 290, my trans.; Martínez Andrade 2004, 74-85).

\section{Literary travelogues}

The high degree of narrative subjectivity and stylistic diversity that marks Graham's and Prieto's travelogues connects their texts to another type of journey account. Although much older in origin, the literary journey narrative gained prominence especially since the late 18th century in the West and has defined the genre in the popular imagination ever since. This body of texts differs from other forms of travel writing for its primarily literary aspirations, focus on travelers' personal feelings and imagination, and blending of inner and outer journeys (Blanton 2002, 11-20; Hayward 2016, 366-67). Modern and postmodern travelogues tend toward greater self-reflexivity and formal experimentation than earlier works, and intertextual, fictional, and metafictional elements often dominate over descriptions of extratextual reality (Blanton 2002, 21-27; Nünning 2008, 26-27). However, many European and North American narratives of journeys through the Americas impose a similar metropolitan "North Atlantic" (Schroder 2011, 119) perspective upon the places and people they describe as the accounts of colonizers, scientists, or social explorers do. In their search for "authentic" experiences off the beaten track, they frame Caribbean and Latin American countries or rural North America as spaces of exotic, inferior socio-cultural alterity (Blanton 2002, 16-17; Pratt 2008, 213-17, 220-22).

In contrast to European and North American journey narratives, Latin American and Caribbean travelogues more regularly draw on national or regional journeys for articulating notions of identity, modernity, and mobility (Pratt 2008, 230). Both modernist and postmodernist travelogues from these areas further continue to interrogate the - external as well as socially internalized - Anglo- and Eurocentrism that have so powerfully shaped prevailing views of their societies (Hayward 369-70). For example, Brazilian modernist writer Mário de 
Andrade employs the format of the ethnographic field journal to deconstruct neo-colonial power relations and discourses of Brazilianness. "We must think, feel like Indians, Chinese, people from Benin, from Java," he argues in his posthumously published $O$ turista aprendiz (Andrade 2015 [1976], 68, my trans.; Hayward 2016, 370; Krakowska 2012, 69-72). The travelogue accordingly reveals and valorizes the rich cultural diversity of the Brazilian North. It shifts back and forth between the perspectives of the creole visitor from the Southern metropolises, on the one hand, and the multiethnic Northern populace, on the other. For instance, the narrative articulates the otherness the metropolitan and foreign tourist experiences in northern cities by likening Belém and Santarém to Cairo and Venice, respectively. However, it simultaneously looks at the visitors from a local, Northern vantage point, from which they appear as a rather homogenous group, both ignorant and alien (Andrade 2015, 73, 87-88, 110, 113; Krakowska 2012, 72-80).

In an even more radical vein, Jamaica Kincaid's A Small Place (1988) embodies postcolonial "countertravel writing" that seeks to undermine the travel genre's ongoing production of otherness and its location in marginalized social and geographic spaces. Written in an essayistic style, the volume presents the angry diatribe of a female Antiguan first-person narrator against the archetypal white male Northern tourist. The text reverses the textual and extratextual hierarchies of knowledge and power of traditional travel writing, as it is the Caribbean "travelee" (Pratt 2008, 8, 133) whose narration conveys and scrutinizes the foreign visitor's perspective. By addressing the tourist as "you," the narrator further collapses the categories of traveler and reader. As she guides them around Antigua, pointing out how different places, objects and people are related to the country's colonial past and neo-colonial present, she forces this dual addressee to discard hegemonic "knowledge" of the Caribbean and engage with their own implication in the island's socio-economic condition (Kincaid 2000; Schroder 2011, 1434). The colonizing gaze of the Northern traveler/reader thus finally turns against itself.

\section{Conclusion}

Based on the premise that narratives actively contribute to discursive constructions of geographies and civilizations, travel writing has been an important means of communicating knowledge, ideas, and imaginaries of the Americas. Journey accounts about the hemisphere have been both trans-oceanic and Inter-American in scope, and they have inspired evergrowing numbers of subsequent works: French and English colonizers would not have thought of sailing to the "New World," had they not read about the splendors of Spanish 
America. Inspired by European exploration accounts, governments of independent nation states in the Americas deployed scientific expeditions to access their own countries' natural resources and prepare settlement endeavors. And numerous individual travelers and readers have critically engaged with the writings of colonizers and settlers, scientists and soldiers, missionaries and socialites, artists and intellectuals.

The relevance of this body of texts further reminds us of the need to expand narrow definitions of the genre and engagements with its distinct varieties. This entails, among others, enlarging the focus to include and interconnect both text-immanent parameters of investigation and travelogues' to social discourses, ideologies, and practices. It further remains to break down the linguistic and ideological barriers that still inform the field of Americas-related travel writing research: The rubric of North American travel writing may equally refer to journey accounts by writers from the United States or Canada about any part of the world or to narratives about their countries penned by Europeans, almost ignoring the contributions of Latin American, Caribbean, African, or Asian travelers. This ignorance also marks especially anglophone scholarship on Caribbean or Latin American travel writing, as it tends to limit this category to texts by Europeans, U.S. Americans, or Canadians about the rest of the hemisphere (Guzmán Rubio 2011, 112). In this context, Inter-American Studies may provide a crucial corrective to this linguistic-scholarly divide and offer the opportunity to better navigate the entangled routes of Inter-American travel and travel writing scholarship.

\section{Works Cited}

Andrade, Mário de. 2015. O turista aprendiz: Edição de texto apurado, anotada e acrescida de documentos. ed. Telê Ancona Lopez and Tatiana Longo Figueiredo. Brasil: Iphan. Orig. pub. 1976.

Blanton, Casey. 2002. Travel Writing: The Self and the World. New York: Routledge.

Boone, Elizabeth Hill. 1994. "Aztec Pictorial Histories: Records without Words.” In Writing Without Words: Alternative Literacies in Mesoamerica and the Andes, eds Elizabeth Hill Boone and Walter D. Mignolo. 50-76. Durham: Duke University Press.

Checa, Jorge. 1998. Experiencia y representación en el siglo de oro: Cortés, Santa Teresa, Gracián, Sor Juana Inés de la Cruz. Valladolid: Junta de Castilla y León.

Cortés, Hernán. 1963. "Segunda carta de relación." In Cartas y Documentos, Introd. Mario Hernández Sánchez-Barba. 32-115. Mexico City: Porrúa. Orig. pub. 1522.

Ette, Ottmar. 2003. Literature on the Move. Trans. Katharina Vester. Amsterdam: Rodopi.

Fernández Bravo, Álvaro. 2007. "Los relatos de viaje en América Latina.” Ministerio de Educación y Cultura de la República Argentina, Buenos Aires. www.bnm.me.gov.ar/ giga1/documentos/EL002325.pdf. 
Graham, Maria Dundas. 1969. Journal of a Residence in Chile during the Year 1822 and a Voyage from Chile to Brazil in 1823. New York: Praeger. Orig. pub. 1824.

Guzmán Rubio, Federico. 2011. "Tipología del relato de viajes en la literatura hispanoamericana: Definiciones y desarrollo.” Revista de Literatura 73, no. enero-junio: 111-30.

Hayward, Jennifer. 2016. "Latin America." In The Routledge Companion to Travel Writing, ed. Carl Thompson. 361-71. London: Routledge.

Humboldt, Alexander von, and Aimé Bonpland. 2007. Relation historique du voyage aux régions équinoxiales du Nouveau Continent. 3 vols. Paris: Bibliothèque Nationale de France. http://gallica.bnf.fr/services/engine/ search/sru?operation=searchRetrieve\& version $=1.2 \&$ collapsing $=$ disabled $\&$ query $=$ dc. relation $\% 20$ all $\% 20 \% 22 \mathrm{cb} 37341712 \mathrm{v} \%$ 22. Orig. pub. 1814-25.

Hume, Brad D. 1999. "The Romantic AND the Technical in Early Nineteenth-Century American Exploration." In Surveying the Record: North American Scientific Exploration to 1930, ed. Edward G. Carter II. 301-16. Philadelphia: American Philosophical Society.

The Journals of the Lewis and Clark Expedition. 2005. Lincoln: University of Nebraska Press and University of Nebraska-Lincoln Libraries, Electronic Text Center. http:// lewisandclarkjournals.unl.edu.

Jurt, Joseph. 2001. "Premières images françaises du Brésil." In As Américas do Sul: O Brasil no contexto latino-americano, Walter Bruno Berg. et al. 204-15. Tübingen: Niemeyer.

Kincaid, Jamaica. 2000. A Small Place. New York: Farrar, Straus, Giroux. Orig. pub. 1988.

Krakowska, Kamila. 2012. "O Turista aprendiz e o outro: A(s) identidades brasileira(s) em trânsito." P: Portuguese Cultural Studies 4, 66-84.

Léry, Jean de. 2009. Histoire d'un voyage fait en la terre du Brésil. Tours: Université François Rabelais, Centre d'Etudes Supérieures de la Renaissance. www.bvh.univtours.fr/Epistemon/XUVA_Gordon1578_L47.pdf. Orig pub. 1578.

Lindquist, Jason H. 2004. "“Under the influence of an exotic nature ... National remembrances are insensibly effaced:' Threats to the European subject in humboldt's personal narrative of travels to the equinoctial regions of the new continent." Humboldt im Netz: International Review for Humboldtian Studies 5, no. 9: 49-64.

Martínez Andrade, Marina. 2004. "Al encuentro con el otro: Un viaje de Guillermo Prieto.” In Espacio, viajes y viajeros, ed. Luz Elena Zamudio. 65-89. Mexico City: UAMIztapalapa and Aldus.

Mignolo, Walter D. 2005. The Idea of Latin America. Oxford: Blackwell.

Nünning, Ansgar. 2008. "Zur Präfiguration/Prämediation der Wirklichkeitsdarstellung im Reisebericht: Grundzüge einer narratologischen Theorie, Typologie und Poetik der Reiseliteratur." In Points of Arrival: Travels in Time, Space, and Self/Zielpunkte: Unterwegs in Zeit, Raum und Selbst, ed. Marion Gymnich. et al. 11-32. Tübingen: Francke.

Pérez-Mejía, Ángela. 2004. A Geography of Hard Times: Narratives about Travel to South America, 1780-1849. Trans. Dick Cluster. Albany: State University of New York Press.

Pratt, Mary Louise. 2008. Imperial Eyes: Travel Writing and Transculturation. London: Routledge. 
Prieto, Guillermo. 2017. Viaje a los Estados Unidos. 3 vols. Alicante: Biblioteca Virtual Miguel de Cervantes. www.cervantesvirtual.com/obras/autor/prieto-guillermo-1818-1897 -10100 . Orig. pub. 1877-78.

Rabasa, José. 1993. Inventing America: Spanish Historiography and the Formation of Eurocentrism. Norman: University of Oklahoma Press.

Roberson, Susan. 2016. "North America/USA." In The Routledge Companion to Travel Writing, ed. Carl Thompson. 351-60. London: Routledge.

Said, Edward W. 1995. Orientalism. London: Penguin. Orig. pub. 1978.

Schroder, Anne. 2011. "Where the Other Half Lives: Touring the Sites of Caribbean Spirit Possession in Jamaica Kincaid's A Small Place." In Postcolonial Travel Writing, eds Justin D. Edwards and Rune Graulund. 116-37. Basingstoke: Palgrave Macmillan.

Slaughter, Thomas P. 2003. Exploring Lewis and Clark: Reflections on Men and Wilderness. New York: Knopf.

van Groesen, Michiel. 2008. The Representations of the Overseas World in the De Bry Collection of Voyages (1590-1634). Amsterdam: Brill. 